11

\title{
Оптические свойства нанокомпозитов на основе сульфидов цинка и олова в нанопористом силикатном стекле
}

\author{
() А.И. Сидоров ${ }^{1}$, Нго Дуи Тунг ${ }^{1}$, Нго Ван Вуํㅜ \\ ${ }^{1}$ Университет ИТМО, \\ 199034 Санкт-Петербург, Россия \\ ${ }^{2}$ Институт химии силикатов им. И.В. Гребенщикова РАН, \\ 199034 Санкт-Петербург, Россия \\ ${ }^{3}$ ФТИ им. А.Ф. Иофффе, \\ 194021 Санкт-Петербург, Россия \\ e-mail: sidorov@oi.ifmo.ru
}

Поступила в редакцию 06.04.2019 г.

В окончательной редакции 06.04.2019 г.

Принята к публикации 07.05.2019 г.

\begin{abstract}
Представлены спектры оптической плотности, люминесценции и комбинационного рассеяния кристаллических микро- и нанодендритов сульфидов цинка и олова в силикатном нанопористом стекле (НПС) со средним размером пор $25 \mathrm{~nm}$. Нанодендриты сульфидов были синтезированы путем сульфидирования нанодендритов цинка и олова, выращенных в порах НПС методом электролиза. Показано, что люминесценция нанодендритов вызвана дефектами кристаллической решетки. Основные полосы спектра комбинационного рассеяния нанодендритов связаны с поперечными и продольными колебательными модами гексагонального $\mathrm{ZnS}$ (вюрцит) и модами растяжения 2 политипа $\mathrm{SnS}_{2}$ с гексагональной элементарной ячейкой. Полученные результаты могут быть использованы при создании химических и биологических сенсоров, а также в фотовольтаике и фотокатализе.
\end{abstract}

Ключевые слова: комбинационное рассеяние, вюрцит, нанодендрит, микродендрит.

DOI: $10.21883 /$ OS.2019.11.48525.135-19

\section{Введение}

Нанокомпозиты на основе низкоразмерных нанопроволок и нанодендритов металлов и полупроводников перспективны для применения в устройствах фотоники, электроники и оптоэлектроники [1-3]. Состав, структура, морфология и размеры нанопроволок определяют оптические и электрические свойства таких нанокомпозитов. Например, в устройствах фотоники и оптоэлектроники изменение состава и диаметра нанопроволок позволяет варьировать ширину запрещенной зоны, что определяет оптические свойства нанокомпозита. Морфология нанопроволок и нанодендритов задает функциональные свойства нанокомпозитов. Существует большое количество методов синтеза двумерных и трехмерных дендритных наноструктур из различных материалов с различными морфологией и свойствами (например, [4-6]).

Сульфид цинка, полупроводник группы $\mathrm{A}^{\mathrm{II}}-\mathrm{B}^{\mathrm{VI}}$ с шириной запрещенной зоны $3.7-3.8 \mathrm{eV}$, представляет интерес для применения в устройствах фотоники и оптоэлектроники УФ диапазона [7-9]. Сульфиды олова $\left(\mathrm{SnS}, \mathrm{Sn}_{2} \mathrm{~S}_{3}\right.$ и $\left.\mathrm{SnS}_{2}\right)$, полупроводники группы $\mathrm{A}^{\mathrm{IV}}-\mathrm{B}^{\mathrm{VI}}$, перспективны в устройствах фотовольтаики, оптоэлектроники и фотокатализа [10-13]. Наноструктуры на основе сульфидов цинка и олова используют в качестве чувствительных элементов газовых сенсоров [12]. В случае сенсорных применений наноструктур из сульфидов цинка и олова используют изменение их оптических свойств, например, люминесценции, либо их электрических свойств при внешних воздействиях.

Силикатные НПС с сообщающимися порами являются удобной матрицей для синтеза наночастиц и наноструктур. Они исходно прозрачны, химически стойки, выдерживают нагрев до высоких температур. В них можно проводить многостадийные химические реакции и внешние воздействия (нагрев, облучение, пропускание электрического тока ит.д.) [14-17]. Изменяя условия синтеза НПС, можно варьировать средний размер пор от единиц до сотен нанометров. После формирования в порах НПС наноструктур поры могут быть заполнены газообразным или жидким аналитом, что представляет интерес для использования таких нанокомпозитов в нано- и микрофлюидной сенсорике [18].

Целью настоящей работы было исследование оптических свойств микро- и нанодендритов кристаллических сульфидов цинка и олова, синтезированных в нанопористых силикатных стеклах.

\section{Методика экспериментов}

В экспериментах использовались силикатные НПС с сообщающимися порами, имеющими средний размер $25 \mathrm{~nm}$. НПС были изготовлены в Институте химии силикатов им. И. В. Гребенщикова РАН. Объемная кон- 


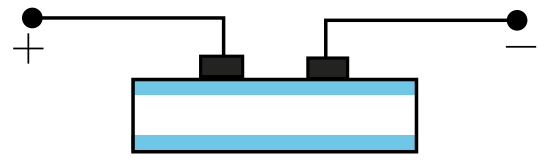

Рис. 1. Схемы электролиза в НПС для формирования микрои нанодендритов из $\mathrm{Zn}$ или $\mathrm{Sn}$.

центрация пор была равна 52-55\%. Каркас НПС более чем на 95\% состоит из $\mathrm{SiO}_{2}$. Для уменьшения потерь на светорассеяние при оптических измерениях поры формировались не во всем объеме стекла, а лишь в приповерхностном слое толщиной $50 \mu \mathrm{m}$. Образцы представляли собой полированные пластины $10 \times 10 \mathrm{~mm}$ толщиной $1 \mathrm{~mm}$.

Микро- и нанодендриты сульфидов цинка и олова формировались в НПС следующим образом. Поры НПС заполнялись $20 \%$ водным раствором $\mathrm{ZnSO}_{4}$ или $\mathrm{Sn}\left(\mathrm{SO}_{4}\right)_{2}$, после чего проводился электролиз с использованием электродов из соответствующего металла. Электроды устанавливались на одной поверхности НПС (рис. 1). Электролиз проводился при напряжении 3-5 V, ток не превышал $0.05 \mathrm{~mA}$. Газы, образующиеся при электролизе, удалялись из пор естественным путем. После электролиза образцы промывались дистиллированной водой в течение $1 \mathrm{~h}$ для удаления прекурсоров. В результате электролиза в приповерхностном слое НПС формировались металлические микро- и нанодендриты из цинка или олова. Для трансформации металлических нанодендритов в сульфидные проводилась термообработка образцов в парах серы при $T=400^{\circ} \mathrm{C}$ в течение $60 \mathrm{~min}$. Для предотвращения попадания в реактор воздуха и окисления металлических нанодендритов в процессе термообработки через реактор пропускался слабый поток аргона. Очевидно, что поперечный размер сформированных нанодендритов не превышал поперечный размер пор, т. е. $25 \mathrm{~nm}$.

Электронно-микроскопические изображения были получены с помощью сканирующего электронного микроскопа (SEM) JSM 7001F (JEOL). Спектры оптической плотности измерялись с помощью спектрофотометра Lambda 650 (PerkinElmer), спектры люминесценции с помощью спектрофлуориметра LS-55 (PerkinElmer). Спектры комбинационного рассеяния были измерены с помощью микроспектрометра комбинационного рассеяния inVia (Renishaw). Все спектральные измерения проводились при комнатной температуре.

\section{Экспериментальные результаты и обсуждение}

На рис. 2 показано SEM-изображение поверхности скола НПС с микродендритами из Zn. Как видно из рисунка, каждый микродендрит состоит из нанодендритов, которые, в свою очередь, состоят из плотно упакованных нанопроволок.
Образцы НПС до формирования в них микро- и нанодендритов прозрачны и бесцветны. После проведения в них электролиза и формирования микро- и нанодендритов из $\mathrm{Zn}$ образцы приобретают коричневую окраску (рис. 3,a), а после сульфидирования - светло-желтую

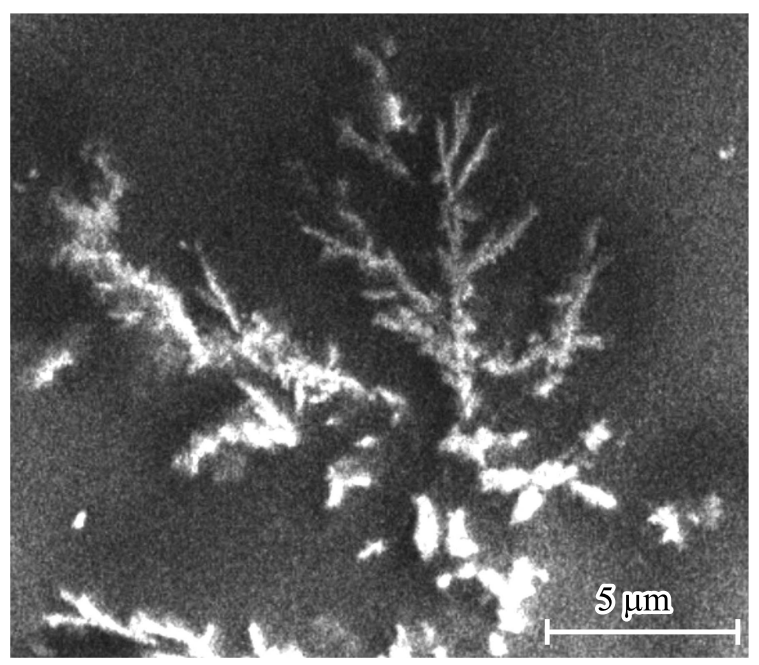

Рис. 2. SEM-изображение поверхности скола НПС с микрои нанодендритами из $\mathrm{Zn}$, сформированными с помощью электролиза.
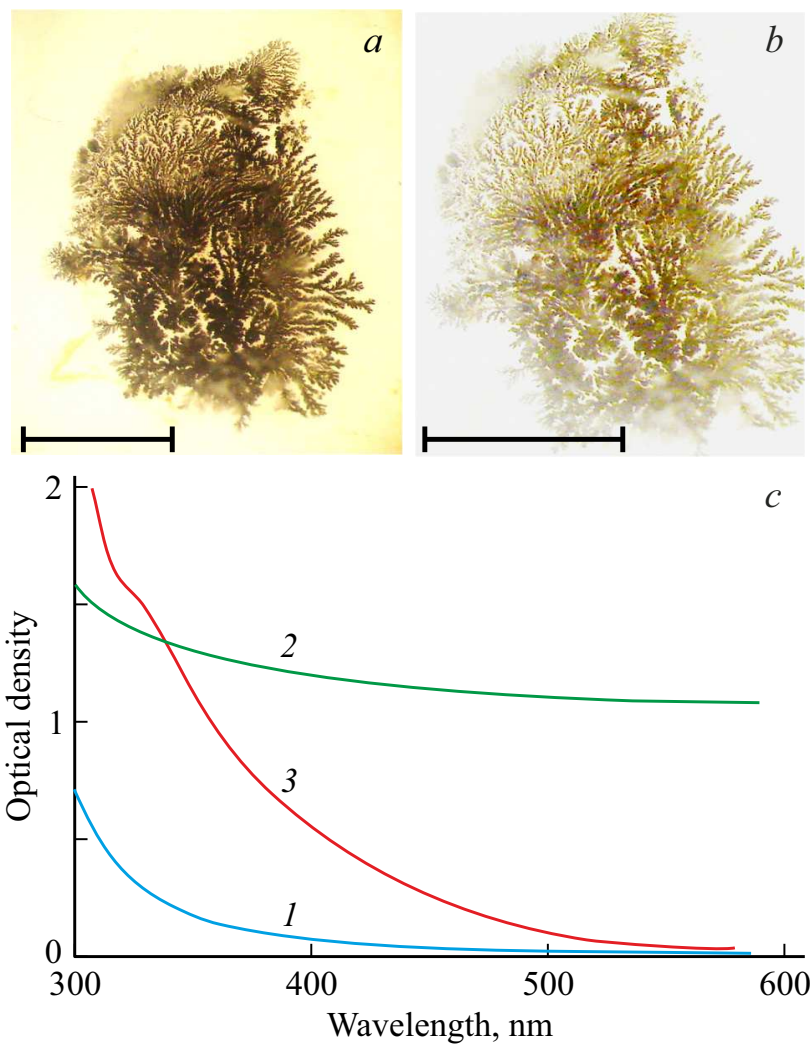

Рис. 3. Фотографии НПС с микродендритами из $\mathrm{Zn}(a)$ $\mathrm{ZnS}(b)$. Вид сверху. Масштабы - $1 \mathrm{~mm} . c$ - спектры оптической плотности НПС без микродендритов (1), с микродендритами из $\mathrm{Zn}(2)$ и микродендритами из $\mathrm{ZnS}(3)$. 

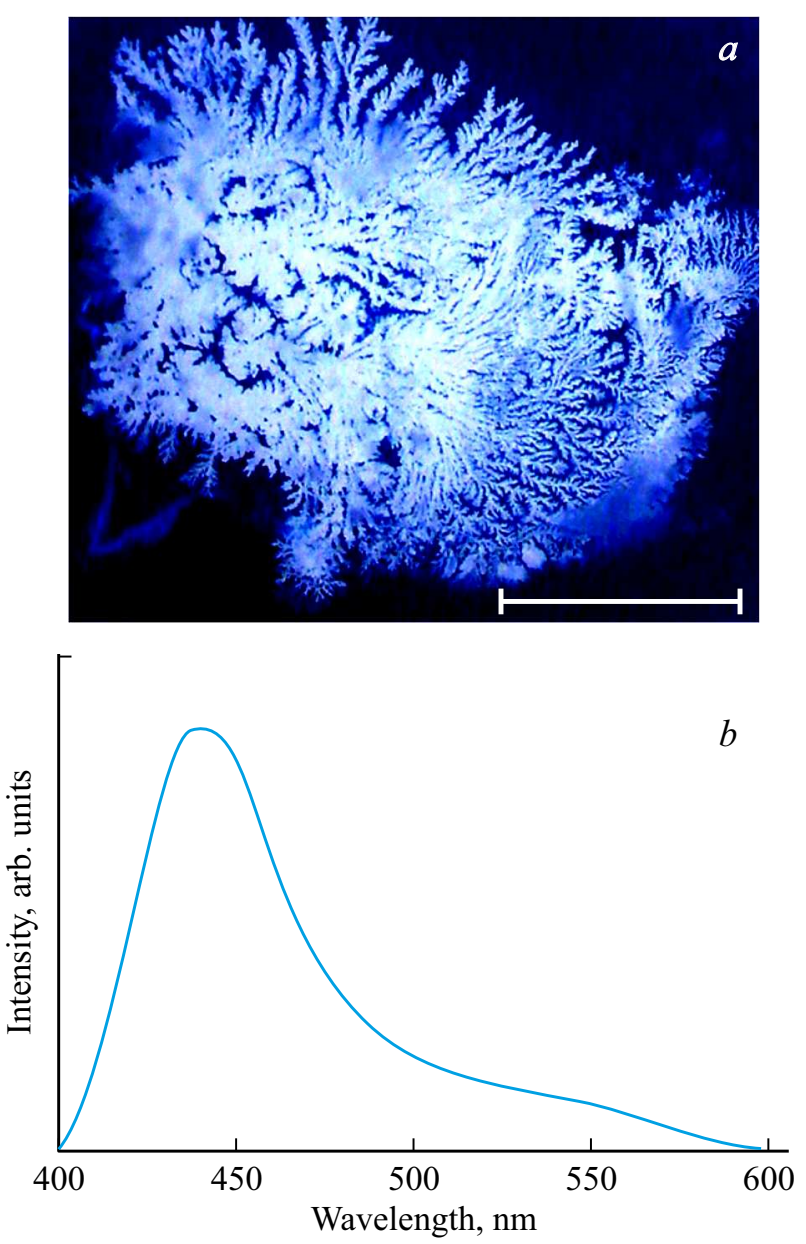

Рис. 4. Фотография люминесценции $(a)$ и спектр люминесценции $(b)$ микро- и нанодендритов из $\mathrm{ZnS}$ в НПС. Длина волны возбуждения $360 \mathrm{~nm}$.

окраску (рис. 3,b). Для наглядности электролиз был остановлен до полного заполнения пористого слоя НПС микродендритами. Несмотря на то, что поперечный размер нанодендритов $\mathrm{ZnS}$ много меньше длины волны, благодаря высокому показателю преломления $\mathrm{ZnS}$, потери на светорассеяние нанокомпозита существенно возрастают, что и определяет цвет образцов. Спектры оптической плотности НПС до и после формирования в них наночастиц $\mathrm{ZnS}$ показаны на рис. 3, $c$. На спектре микродендритов $\mathrm{ZnS}$ на длине волны $\lambda=340 \mathrm{~nm}$ наблюдается экситонная полоса поглощения, что хорошо согласуется с шириной запрещенной зоны кристаллического $\mathrm{ZnS}\left(E_{g}=3.7-3.8 \mathrm{eV}\right)$ и указывает на отсутствие квантово-размерных эффектов.

Фотография люминесценции НПС с микро- и нанодендритами из $\mathrm{ZnS}$ и ее спектр показаны на рис. 4. Из рисунка видно, что в спектре люминесценции присутствуют две перекрывающиеся полосы с максимумами на $\lambda=440$ и 530-550 nm. Голубая полоса связана с излучательной рекомбинацией в вакансиях $\left(V_{\mathrm{Zn}^{-}}\right)$, а желтозеленая полоса вызвана излучательной рекомбинацией в дважды заряженной вакансии серы в кристаллической решетке [19]. Экситонная люминесценция в данном случае не наблюдается из-за большой длины волны возбуждения $(\lambda=360 \mathrm{~nm})$.

Спектр комбинационного рассеяния микро- и нанодендритов из $\mathrm{ZnS}$ в НПС показан на рис. 5. Спектр имеет полосы, характерные для $\mathrm{ZnS}$ с кристаллической решеткой вюрцита [20]. Широкая полоса максимумом на $v=270 \mathrm{~cm}^{-1}$ связана с поперечными оптическими (ТО) фононными модами $\left(\mathrm{A}_{1}(\mathrm{TO}), \mathrm{E}_{1}(\mathrm{TO})\right)$. Интенсивная полоса с максимумом на $v=340 \mathrm{~cm}^{-1}$ может быть поставлена в соответствие с продольными оптическими $(\mathrm{LO})$ модами $\mathrm{A}_{1}(\mathrm{LO})$ и $\mathrm{E}_{1}(\mathrm{LO})$. Наконец, полоса с

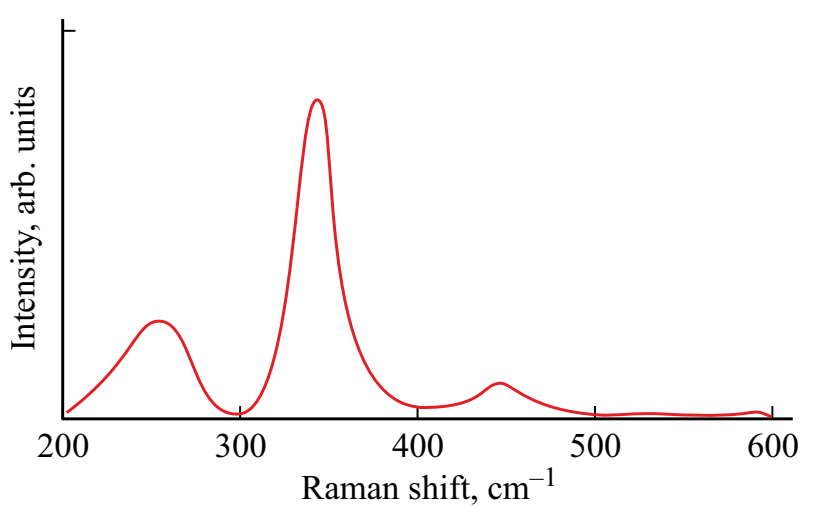

Рис. 5. Спектр комбинационного рассеяния микро- и нанодендритов из $\mathrm{ZnS}$ в НПС.
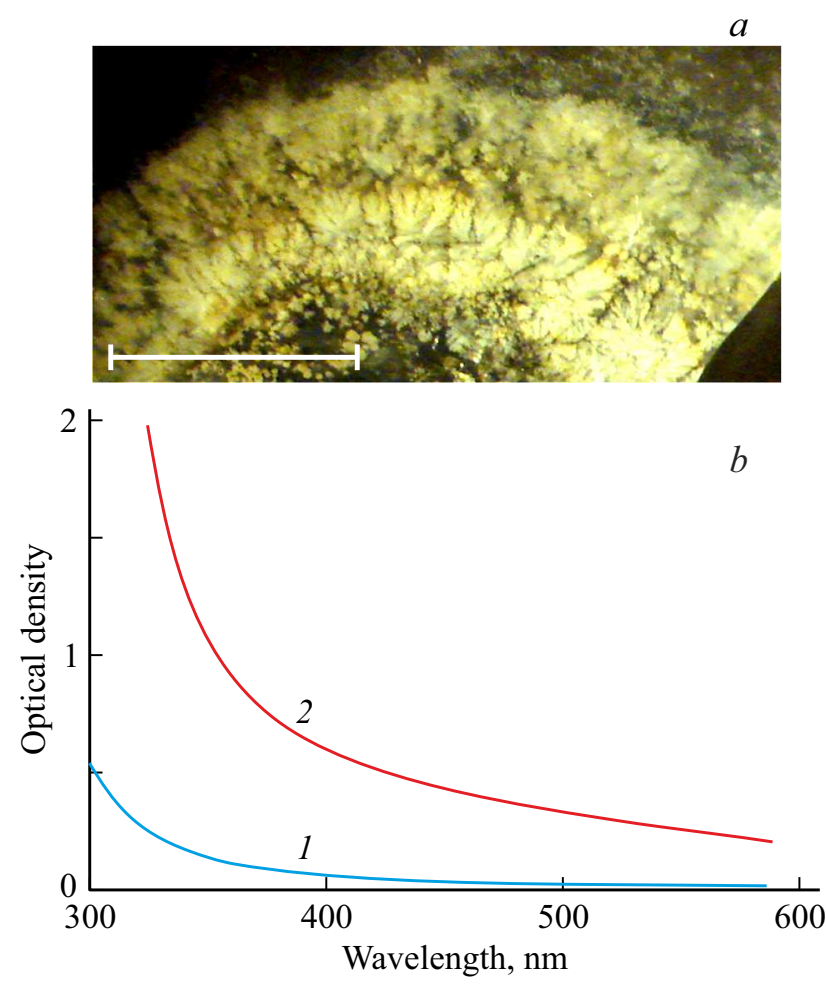

Рис. 6. Фотографии НПС с микродендритами из $\mathrm{SnS}_{2}(a)$. Вид сверху. Масштаб - $1 \mathrm{~mm} . b-$ спектры оптической плотности НПС без микродендритов (1) и микродендритами из $\mathrm{SnS}_{2}(2)$. 


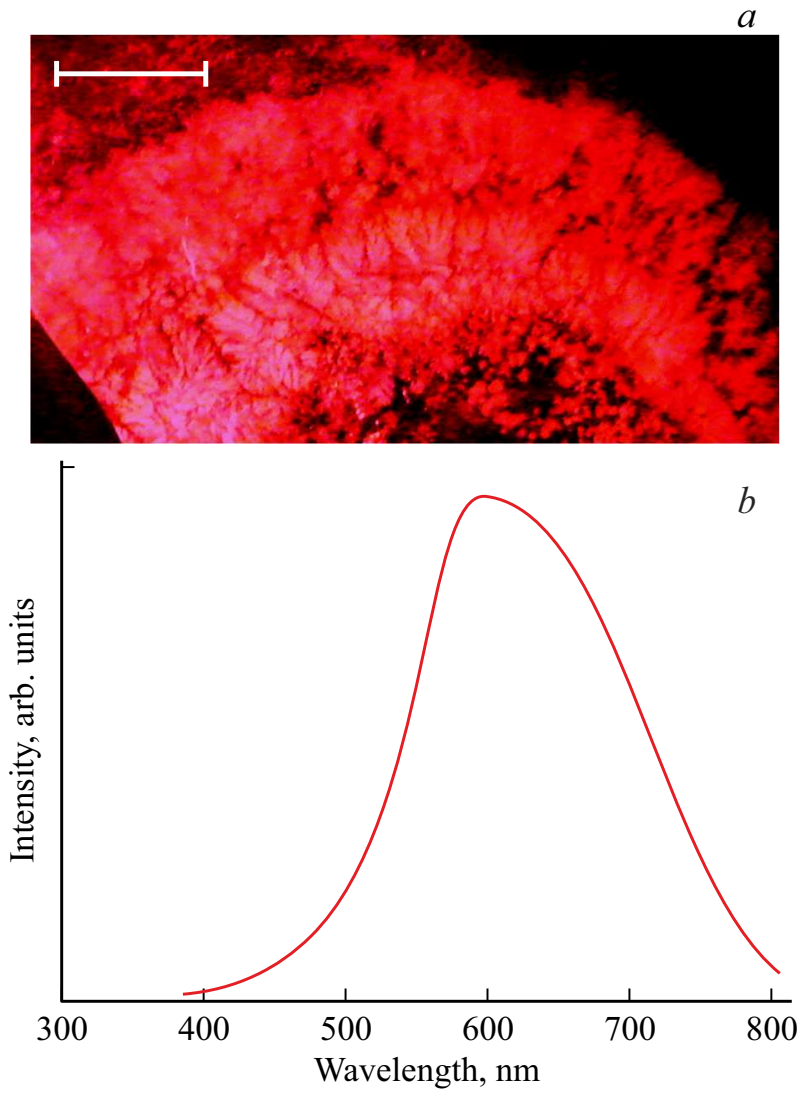

Рис. 7. Фотография люминесценции $(a)$ и спектр люминесценции $(b)$ микро- и нанодендритов из $\mathrm{SnS}_{2}$ в НПС. Длина волны возбуждения $360 \mathrm{~nm}$.

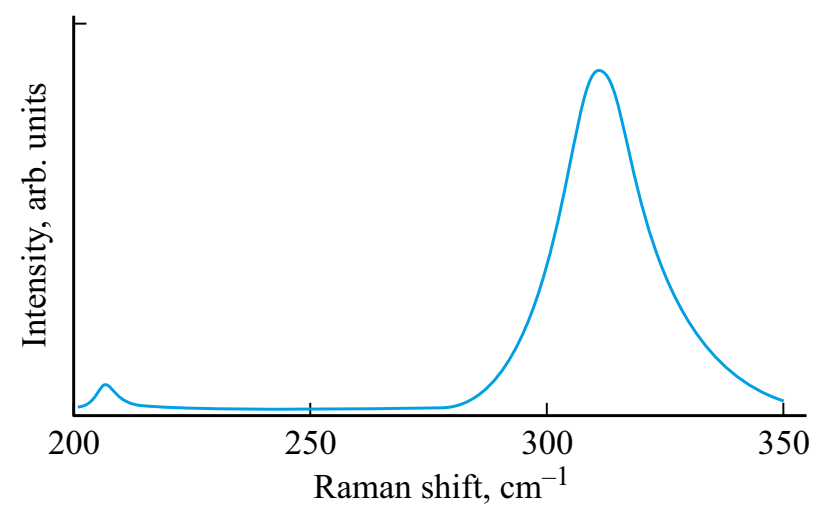

Pис. 8. Спектр комбинационного рассеяния микро- и нанодендритов из $\mathrm{SnS}_{2}$ в НПС.

максимумом на $v=440 \mathrm{~cm}^{-1}$ может представлять собой комбинации продольных и поперечных мод оптической $(\mathrm{O})$ и акустической $(\mathrm{A})$ ветвей: TA + LO и LA + LO.

После сульфидирования микро- и нанодендритов из $\mathrm{Sn}$ в НПС в нем сформировались дендриты сульфида олова светло-желтого цвета (рис. 6,a). Известно, что сульфид олова может существовать в трех стехиометрических состояниях: $\mathrm{SnS}, \mathrm{Sn}_{2} \mathrm{~S}_{3}$ и $\mathrm{SnS}_{2}$. Сульфиды $\mathrm{SnS}, \mathrm{Sn}_{2} \mathrm{~S}_{3}$ имеют черно-коричневую окраску, а $\mathrm{SnS}_{2}$ имеет желтый цвет. Поэтому можно утверждать, что в процессе сульфидирования $\mathrm{Sn}$ трансформируется в $\mathrm{SnS}_{2}$. Это подтверждается также спектрами комбинационного рассеяния (см. ниже). Монокристаллический $\mathrm{SnS}_{2}$ имеет ширину запрещенной зоны $2.2 \mathrm{eV}$, слоистую структуру и три политипа: $2 \mathrm{H}, 4 \mathrm{H}, 18 \mathrm{R}$ [21]. Вид спектра оптической плотности НПС с микро- и нанодендритами из $\mathrm{SnS}_{2}$ (рис. 6, $b$, кривая 2) определяется в первую очередь высоким светорассеянием в коротковолновой области спектра и поглощением на дефектах в длинноволновой области.

Фотография люминесценции НПС с микро- и нанодендритами из $\mathrm{SnS}_{2}$ и ее спектр показаны на рис. 7. Широкая полоса люминесценции занимает спектральный интервал 500-750 $\mathrm{nm}$ и имеет максимум на $\lambda=580 \mathrm{~nm}$. Данная полоса люминесценции связана с межзонными и экситонными переходами в кристаллическом $\mathrm{SnS}_{2}$, а в длинноволновой ее части - с излучательной рекомбинацией в кристаллических дефектах [22].

Спектр комбинационного рассеяния микро- и нанодендритов из $\mathrm{SnS}_{2}$ в НПС показан на рис. 8. На спектре наблюдаются две полосы на частотах 205 и $315 \mathrm{~cm}^{-1}$, характерные для $2 H$ политипа $\mathrm{SnS}_{2}$ с гексагональной элементарной ячейкой и пространственной группой $D_{3} d^{3}(P \overline{3} m 1)$ [21-24]. Низкочастотная мода, имеющая малую интенсивность, соответствует дважды вырожденной $E_{g}$-моде и связана с плоскостными колебаниями типа растяжения атомов серы. Интенсивная высокочастотная мода соответствует моде $A_{1 g}$, которая связана с внеплоскостными колебаниями типа растяжения атомов серы.

\section{Заключение}

Экспериментально показано, что проведение электролиза водных растворов солей цинка и олова в поpax НПС с последующим сульфидированием позволяет сформировать в порах НПС микро- и нанодендриты сульфидов цинка и олова. Синтезированные дендриты обладают люминесценцией, связанной с дефектами кристаллической решетки. Основные полосы спектра комбинационного рассеяния нанодендритов связаны с поперечными и продольными колебательными модами гексагонального $\mathrm{ZnS}$ (вюрцит) и модами растяжения $2 \mathrm{H}$ политипа $\mathrm{SnS}_{2}$ с гексагональной элементарной ячейкой. Полученные результаты могут быть использованы при создании химических и биологических сенсоров, а также в фотокатализе. Описанные нанокомпозиты могут также найти применение в фотовольтаике и в качестве материала катодов для литиевых батарей.

\section{Финансирование работы}

Работа выполнена при финансовой поддержке Министерства образования и науки Российской Федерации (Проект 16.1651.2017/4.6). 
НПС были синтезированы в Институте химии силикатов им. И.В. Гребенщикова РАН в рамках программы фундаментальных научных исследований государственных академий наук на 2013-2020 годы (тема № 00972018-0004).

Электронно-микроскопические исследования выполнены с использованием оборудования федерального ЦКП „Материаловедение и диагностика в передовых технологиях“, поддержанного Минобрнауки России (Уникальный идентификатор проекта RFMEFI62117X0018).

\section{Конфликт интересов}

Авторы заявляют, что у них нет конфликта интересов.

\section{Список литературы}

[1] Lieber C.M. // MRS Bull. 2003. V. 28. P. 486.

[2] Samuelson L. // Mater. Today. 2003. V. 6. P. 22.

[3] Xia Y., Yang P., Sun Y., Wu Y., Mayers B., Gates B., Yin Y., Kim F., Yan H. // Adv. Mater. 2003. V. 15. P. 353.

[4] Yan H., He R., Johnson J., Law M., Saykally R.J., Yang P. // J. Am. Chem. Soc. 2003. V. 125. P. 4728.

[5] Zhou J., Ding Y., Deng S.Z., Gong L., Xu N.S., Wang Z.L. // Adv. Mater. 2005. V. 17. P. 2107.

[6] May S.J., Zheng J.-G., Wessels B.W., Lauhon L.J. // Adv. Mater. 2005. V. 17. P. 598.

[7] Islam M.M., Ishizuka S., Yamada A. // Solar Energy Mater. Solar Cells. 2009. V. 93. P. 970.

[8] Yuan J.H., He F.Y., Sun D.C., Xia X.H. // Chem. Mater. 2004. V. 16. P. 1841.

[9] Valeev R.G., Romanov E.A., Khokhryakov S.V. // Bull. Russ. Acad. Sci. Physics. 2011. V. 75. P. 1480.

[10] Reddy K.T.R., Reddy N.K., Miles R.W. // Sol. Energ. Mater. Sol. Cells. 2006. V. 90. P. 3041.

[11] Lei Y., Song S., Fan W., Xing Y., Zhang H. // J. Phys. Chem. C. 2009. V. 113. P. 1280.

[12] Motevalizadeh L., Khorshidifar M., Abrishami M.E., Mohagheghi M.M.B. // J. Mater. Sci. 2013. V. 24. P. 3694.

[13] Zhu H., Yang D., Ji Y., Zhang H., Shen X. // J. Mater. Sci. 2005. V. 40. P. 591.

[14] Kreisberg V.A., Antropova T.V. // Microporous Mesoporous Mater. 2014. V. 190. P. 128.

[15] Andreeva O.V., Obyknovennaya I.E., Gavrilyuk E.R., Paramonov A.A., Kushnarenko A.P. // J. Opt. Technol. 2005. V. 72. P. 916.

[16] Gutina A., Antropova T., Rysiakiewicz-Pasek E., Virnik K., Feldman Y. // Microporous Mesoporous Mater. 2003. V. 58. P. 237.

[17] Vinogradova O.P., Obyknovennaya I.E., Sidorov A.I., Klimov V.A., Shadrin E.B., Khanin S.D., Khrushcheva T.A. // Phys. Sol. State. 2008. V. 50. P. 768.

[18] Hunt H.C., Wilkinson J.S. // Microfluid. Nanofluid. 2008. V. 4. P. 53.

[19] Physics and Chemistry of II-VI Compounds. / Ed. by M. Aven, J.S. Prener, North Holland, Amsterdam; Interscience (Wiley). 1967. 324 p.

[20] Cheng Y.C., Jin C.Q., Gao F., Wu X.L., Zhong W., Li S.H., Chu P.K. // J. Appl. Phys. 2009. V. 106. 123505.
[21] Utyuzh A.N., Timofeev Y.A., Stepanov G.N. // Phys. Sol. State. 2010. V. 52. P. 352.

[22] Kuzuba T., Era K., Ishizawa Y. // Physics Lett. 1974. V. 46A. P. 413.

[23] Shibata T., Kambe N., Muranishi Y., Miura T., Kishi T. // J. Phys. D.: Appl. Phys. 1990. V. 23. P. 719.

[24] He M., Yuan L.-X., Huang Y.-H. // RSC Advances. 2013. V. 3. P. 3374. 